\title{
Pelatihan Tata Rias Pengantin bagi Wanita Tuna Susila dalam Meningkatkan Kemandirian Usaha
}

\author{
Yuda Setia Laksana ${ }^{\bowtie}$, S. Sholih, Mochamad Naim
}

Jurusan Pendidikan Luar Sekolah, FKIP Universitas Sultan Ageng Tirtayasa

\section{Info Artikel}

\section{Sejarah Artikel:}

Diterima Februari 2017

Disetujui Mei 2017

Dipublikasikan Juni 2017

\section{Keywords:}

training; prostitutes; self

reliance enterprises.

\begin{abstract}
Abstrak
Tujuan penelitian ini mengetahui proses pelaksanaan, hasil, dan faktor penghambat pelaksanaan kegiatan pelatihan. Metode penelitian menggunakan pendekatan deskriptif. Peneliti menggunakan pedoman wawancara, dan pedoman observasi sebagai teknik pengumpulan data. Keabsahan data menggunakan triangulasi sumber, metode dan teori. Analisis data menggunakan tiga tahapan reduksi data, penyajian data, dan simpulan. Hasil penelitian menunjukkan bahwa pelatihan terbagi menjadi tiga jurusan yaitu keterampilan tata rias, tata boga, dan menjahit. Pelaksanaan pelatihan tata rias pengantin dalam prosesnya menggunakan tiga tahapan, pra pelatihan, peserta pelatihan, dan pelaksanaan pelatihan. Hasil pelatihan, peserta mampu mandiri dan dapat berwirausaha di bidang pelatihan. Akan tetapi setelah lulus masih banyak peserta pelatihan yang tidak berwirausaha sendiri. Adapun faktor penghambat yang paling berpengaruh dalam proses pelatihan adalah kurangnya sarana dan prasarana.
\end{abstract}

\begin{abstract}
The purpose of this study was to determine implementation process, inhibiting factors and results of the implementation of training activities. The research method used descriptive approach. Researchers used interview guides, and observation guidelines as data collection techniques. Validity of data using triangulation of sources, methods and theories. Data analysis using three stages, data presentation, and conclusion. The results indicate that the training was divided into three departments: makeup, culinary, and sewing skills. Implementation of bridal makeup training in the process using three stages, pretraining, training participants, and training implementation. The results of the training, participants can be independent and can entrepreneurship in the field of training. However, after graduating there are many trainees who are not selfemployed. The most important inhibiting factor in the training process is the lack of facilities and infrastructure.
\end{abstract}

Alamat korespondensi:

E-mail: setialaksanayuda@ymail.com 


\section{PENDAHULUAN}

Bagi dunia pendidikan, era globalisasi ini telah mendorong persaingan yang cukup ketat. Persaingan yang semakin ketat telah mendorong pendidikan membuat sebuah terobosan dalam mengembangkan produk atau jasa dengan menjadikan kualitas sebagai kunci keterampilan dalam meningkatkan daya saing. Salah satu pelayanan pemerintah yang dibutuhkan oleh masyarakat adalah pendidikan. Karena pendidikan merupakan suatu kebutuhan yang sangat penting bagi masyarakat. Seperti telah termaktub dalam pembukaan UUD Negara Indonesia, bahwa tugas negara adalah untuk mencerdaskan kehidupan bangsa, oleh sebab itu maka pendidikan menjadi sebuah hal pokok yang penting dalam tugas pemerintah. Pelayanan pendidikan adalah hal yang menjadi salah satu kebutuhan pokok ketika dibentuk negara, maka negara haruslah membuat sebuah sistem pendidikan atau kebijakan-kebijakan yang disesuaikan dengan tugas dan pemerintah dan kebutuhan masyarakat.

Menurut Undang-undang Sisdiknas Tahun 2003 Pasal 26 ayat 3, adalah pendidikan kecakapan hidup (life skill) pendidikan yang memberikan: (1) kecakapan personal, (2) kecakapan sosial, (3) kecakapan konstektual, dan (4) kecakapan vokasional untuk bekerja atau usah mandiri. Kecakapan-kecakapan tersebut dapat dikelompokan menjadi dua, yaitu kecakapan umum (general life skill) dan kecakapan khusus (specifices skill).

Pembangunan kesejahteraan sosial di Indonesia telah menunjukkan banyak kemajuan terutama bagi warga masyarakat yang kurang beruntung dan rentan. Dalam konsep penyelenggaraan kesejahteraan social, warga masyarakat tersebut dikenal dengan sebutan Penyandang Masalah Kesejahteraan Sosial (PMKS) dan masyarakat miskin yang menjadi kelompok sasaran pelayanan sosial. Kemajuan kondisi sosial masyarakat terutama PMKS seperti tercermin pada indikator sosial, antara lain jangkauan pelayanan sosial di satu sisi dan penurunan jumlah PMKS serta masyarakat miskin, kemandirian dan keberfungsian sosial PMKS masyarakat miskin, serta tercermin pada tumbuh berkembangnya kelembagaan sosial, organisasi sosial, pranata sosial, pilar-pilar partisipasi sosial (volunteerism), dan nilai-nilai kesetiakawanan sosial yang menjadi karakteristik dan jati diri Bangsa Indonesia.

Balai Pemulihan dan Pengembangan Sosial Provinsi Banten dibangun pada Tahun 1983 sesuai dengan Surat Keputusan Menteri Sosial Republik Indonesia Nomor: 95/DIR/2/KAK/IV/83, Tanggal 01 Juni 1983. Balai ini sebelumnya bernama SPA (Sasana Penyantunan Anak), kemudian diubah menjadi PSBR (Panti Sosial Bina Remaja), kemudian diubah lagi menjadi BPPS (Balai Pemulihan dan Pengembangan Sosial) Provinsi Banten.

Balai Pemulihan dan Pengembangan Sosial Provinsi Banten adalah Unit Pelaksana Teknis Dinas (UPTD) pada Dinas Sosial dan Tenaga Kerja Provinsi Banten seperti yang tercantum dalam Keputusan Gubernur Banten Nomor 41 Tahun 2002. Balai Pemulihan dan Pengembangan Sosial merupakan Unit Pelaksana Teknis pada Dinas Sosial Provinsi Banten yang dilaksanakan pembinaan dan rehabilitasi sosial kepada remaja putus sekolah, gelandangan pengemis, wanita tuna susila, para penyandang cacat dan korban napza yang dibentuk berdasarkan Peraturan Daerah Nomor 3 tahun 2008 tentang pembentukan Organisasi dan Tata Kerja Dinas Daerah Provinsi Banten dan berdasarkan Peraturan Daerah No 3 Tahun 2012 tentang Pembentukan Organisasi Perangkat Daerah Balai Pemulihan dan Pengembangan Sosial tetap sebagai Balai Pemulihan dan pengembangan Sosial dibawah Dinas Sosial Provinsi Banten atau sebagai UPT pada Dinas Sosial Provinsi Banten. Maka Balai Pemulihan dan Pengembangan Sosial mempunyai peran terhadap kegiatan rehabilitasi social. Dalam hal itu bisa dilihat dari Tugas Pokok dan Misi Balai Pemulihan dan Pengembangan Sosial.

Balai Pemulihan dan Pengembangan Sosial mempunyai tugas pokok melaksanakan kegiatan teknis operasional dinas di bidang pemulihan dan pengembangan sosial. Misi Balai Pemulihan dan Pengembangan Sosial yaitu (a) meningkatkan kualitas pekerja sosial sebagai 
pelaksana/pemberi pelayanan dan rehabilitasi sosial, (b) memperluas jangkauan dan meningkatkan mutu pelayanan kesejahteraan sosial melalui kerja sama atau kemitraan dengan perusahaan dan lembaga-lembaga sosial melalui baik milik pemerintah maupun swasta.

Balai Pemulihan dan Pengembangan Sosial mempunyai tugas pokok melaksanakan kegiatan teknis operasional dinas dibidang pemulihan dan pengembangan sosial. Balai Pemulihan dan Pengembangan Sosial mempunyai fungsi: (1) penyusunan rencana teknis operasional di bidang pemulihan dan pengembangan sosial; (2) pelaksanaan kebijakan teknis operasional di bidang pemulihan dan pengembangan sosial; (3) pengelolaan di bidang pemulihan sosial; (4) pengelolaan di bidang pengembangan sosial; (5) pengelolaan di bidang sarana dan prasarana balai; dan (6) pelaksanaan urusan ketatausahaan. Berbagai penyediaan pelayanan kesejahteraan sosial oleh berbagai pemangku kepentingan di Indonesia, telah meningkat cukup berarti dari waktu ke waktu. Namun demikian upaya pelayanan tersebut, masih jauh dari yang diharapkan apabila dibandingkan dengan populasi PMKS yang jauh lebih besar jumlahnya.

Sumber Daya Manusia (SDM) merupakan faktor yang paling menentukan dalam setiap organisasi, karena di samping sumber daya manusia salah satu unsur kekuatan daya saing bangsa, sumber daya manusia bahkan sebagai penentu utama. Oleh sebab itu, sumber daya manusia harus memiliki kopetensi dan kinerja tinggi demi kemajuan perkembangan ilmu pengetahuan dan teknologi yang terus berkembang pesat. Secara langsung disadari maupun tidak disadari pasti memiliki dampak yang luar biasa terhadap perkembangan organisasi. Perubahan tersebut selain memiliki dampak positif di sisi lain dapat berdampak negatif terhadap organisasi. Dengan demikian dibutuhkan kualitas pegawai yang mampu menyikapi perubahan yang tidak pernah berhenti. Kualitas pegawai merupakan unsur yang strategis dalam menentukan sehat tidaknya suatu organisasi. Pengembangan SDM yang terencana dan berkelanjutan merupakan kebutuhan yang mutlak terutama untuk masa depan organisasi. Dalam kondisi lingkungan tersebut, manajemen dituntut untuk mengembangkan cara baru dalam mempertahankan pegawai pada produktifitas tinggi serta mengembangkan potensinya agar memberikan kontribusi maksimal pada organisasi. Masalah kualitas pegawai yang kelihatannya hanya merupakan masalah internal dari suatu organisasi sesungguhnya mempunyai hubungan yang erat dengan masyarakat luas sebagai pelayanan publik yang diukur dari kinerja.

Namun demikian di samping banyaknya kemajuan yang telah dicapai dalam pembangunan kesejahteraan sosial, sangat besar tantangan yang dihadapi Semakin kompleksnya permasalahan kesejahteraan sosial dan masih banyaknya yang belum sepenuhnya terselesaikan sejalan dengan dinamika sosial ekonomi masyarakat. Untuk itu, maka penanganan masalah kesejahteraan sosial melalui pembangunan kesejahteraan sosial terus dilanjutkan.

Sasaran pembangunan bidang kesejahteran sosial yang dilaksanakan Dinas Sosial Provinsi Banten sebagai contoh melalui Balai Pemilihan dan Pengembangan Sosial, yakni melaksanakan pembinaan dan rehabilitasi sosial bagi para gelandangan dan pengemis (Gepeng), Wanita Tuna Susila (WTS), korban narkotika psikotropika dan zat adiktif (Napza) dan remaja putus sekolah terlantar.

Ada sejumlah permasalahan mendasar yang dihadapi antara lain: (a) cakupan atau jangkauan pelayanan program kesejahteraan sosial yang dibagi ke dalam empat pilar intervensi masih sangat terbatas, (b) kegiatan bantuan dan jaminan sosial bagi PMKS masih tumpang tindih satu sama lain, (c) pemerintah daerah belum optimal dalam memberikan pelayanan kesejahteraan sosial bagi PMKS yang tercermin dalam aspek pelayanan kelembagaan yang disediakan dan penyediaan anggaran, (d) peran pemerintah yang masih dominan dalam pelayanan program pemberdayaan PMKS dan PSKS sehingga mengurangi esensi dari upaya pemberdayaan sosial itu sendiri, (e) 
Peran masyarakat melalui organisasi nirlaba dan dunia usaha dalam pelayanan kesejahteraan sosial belum terarah dan terdayagunakan secara optimal, (f) kapasitas sumber daya manusia pelaksana pelayanan kesejahteraan sosial dalam hal substansi teknis dan praktis masih terbatas, dan (g) koordinasi dan komunikasi pada berbagai sektor dan level masih belum optimal.

Permasalahan kesejahteraan sosial tuna susila khususnya wanita tuna susila tidak hanya bersifat ekonomi, tetapi juga menyangkut masalah lain yang bersifat mental, sosial dan budaya. Dengan demikian, permasalahan sosial tuna susila cukup kompleks, sehingga pemerintah dalam hal ini Departemen Sosial melakukan penanganan secara terus menerus melalui berbagai pendekatan, sesuai dengan jenis permasalahan yang melekat pada diri tuna susila itu sendiri. Pembinaan mantan WTS bertujuan menganalisis dan menemukan masalah umum, program pembinaan, keunggulan dan kelemahan serta menemukan pengembangan model pembinaan akhlak mantan WTS, dan membina WTS untuk mempunyai keahlian-keahlian guna membuka usaha-usaha yang membantu ekonominya. Hal ini berorientasi pada kemandirian berusaha bagi WTS. Jika tujuan ini tercapai tentunya akan memiliki manfaat mantan WTS dan masyarakat.

Menurut Ryan \& Lynch (Hendriyani, 2005) berpendapat bahwa kemandirian adalah kemampuan dalam mengatur tingkah laku, menyeleksi dan membimbing keputusan dan perilakunya tersebut tanpa ada paksaan serta pengontrolan maupun pengawasaan dari orang lain. Kemampuan tersebut berarti individu mampu mengelola potensi yang dimilikinya dan siap menerima konsekuensi dari keputusan yang diambil. Sebagaimana Siahaan (Ningsih, 2005) yang menjelaskan bahwa kemandirian adalah kemampuan untuk berdiri sendiri atau menggali potensi-potensi yang ada pada dirinya, agar tidak tergantung pada orang lain, baik dalam merumuskan kebutuhan-kebutuhannya, maupun dalam mengatasi kesulitan dan tantangan yang dihadapinya serta bertanggungjawab dan berdiri sendiri. Lerner (Budiman, 2006) memberikan konsep mengenai kemandirian, yaitu mencakup kebebasan untuk bertindak, tidak bergantung kepada orang lain, tidak terpengaruh lingkungan dan bebas mengatur kebutuhan sendiri. Konsep yang diberikan oleh Lerner ini hampir senada dengan yang diajukan Watson \& Lindgren (Budiman, 2006) bahwa kemandirian ialah kebebasan untuk mengambil inisiatif, mengatasi hambatan, gigih dalam usaha, dan melakukan sendiri segala sesuatu tanpa bantuan orang lain. Dengan kata lain kemandirian tersebut merupakan kemampuan dalam mengelola diri sehigga ia mampu mengoptimalkan semua potensi yang dimiliki dalam berusaha memenuhi kebutuhan hidupnya.

Sehubungan kondisi permasalahan kesejahteraan sosial yang kerap ditemui, maka dalam penelitian ini memfokuskan permasalahan pada wanita tuna susila di Provinsi Banten yang akan direkrut untuk memperoleh pembinaan melalui kegiatan dan pengembangan sosial yang dilaksanakan di Balai Pemulihan dan Pengembangan Sosial agar berjalan secara lebih terarah, terencana, terkoordinasi dan berkesinambungan. Kegiatan pembinaan dilakukan dengan adanya pelatihan keterampilan tata rias pengantin.

Pendidikan keterampilan tata rias pengantin menjadi sebuah angin segar bagi dunia pendidikan serta msyarakat. Hal ini menitikberatkan kepada kemampuan yang disesuaikan dengan kebutuhan pasar yang merupakan harapan dari sebagian besar masyarakat. Bangsa indonesia dengan keanekaragaman suku bangsa serta kebudayaan telah mengekspersikan berbagai unsur budaya, antara lain tata rias pengantin. Dengan desain yang menarik, komposisi yang harmonis serta bentuk-bentuk ragam hiasnya mempunyai karakteristik yang mencolok. Tata rias pengantin tidak hanya sekedar menarik perhatian orang dalam upacara perkawinan, tetapi juga dapat menciptakan suasana resmi dan hidmat, sehingga perwujudannya tidak hanya mewah dan meriah saja namun mengandung lambanglambang dan makna tertentu (Saleh \& Jafar, 1991). Menurut Harpi Melati Temanggung (1998:11), "Seorang pengantin diibaratkan 
seperti raja atau ratu sehari, karena busana serta riasan wajahnya meniru seorang raja ataupun ratu". Demikian pula halnya dengan riasan wajah pengantin gaya Solo pun sebagian besar menirukan dandanan seorang raja ataupun ratu dari Kraton Solo, baik mengenai merias wajah, sanggul, busana ataupun tata cara upacara adatnya.

\section{METODE}

Berdasarkan pada pokok permasalahan yang dikaji, yaitu mengenai pemberdayaan Wanita Tuna Susila (WTS) melalui Pelatihan Tata Rias Pengantin di Balai Pemulihan dan Pengembangan Sosial Provinsi Banten, maka penelitian ini menggunakan metode pendekatan penelitain kualitatif. Penelitian ini menggunakan metode penelitian kualitatif yang bersifat deskriptif dengan tujuan dari metode ini adalah untuk memecahkan permasalahan yang nyata yang terjadi. Begitu pula, penelitian deskriptif sudah cukup memadai dalam penelitian evaluasi untuk menemukan kekuatan dan kelemahan dari beragam unsur yang terlibat dengan suatu analisis. Metode deskriptif ini digunakan secara sistematis fakta atau karakteristik populasi tertentu atau bidang tertentu dalam hal ini bidang secara aktual dan cermat. Penelitian ini juga untuk menganalisis suatu fakta, gejala dan peristiwa yang terjadi di lapangan sebagaimana adanya konteks ruang dan waktu serta situasi lingkungan pendidikan secara alami. Selain itu penelitian kualitatif dapat digunakan untuk menyusun hipotesis berkenaan dengan konsep dan prinsip pendidikan berdasarkan data dan informasi yang diperoleh di lapangan sehingga dapat dilakukan penelitan lebih lanjut.

Tempat penelitian berada di Balai Pemulihan dan Pengembangan Sosial (BPPS) di Pasir Ona Jaura Rangkasbitung Lebak, Banten. Sumber data utama dalam penelitian kualitatif ini adalah kata-kata, ucapan, mimik, perbuatan, tingkah laku, dan lain-lain, selebihnya adalah data tambahan seperti dokumen, arsip dan lainlain. Data utama diperoleh melalui sumber lisan dan sumber tertulis. Sumber lisan diperoleh dari wawancara dengan kepala lembaga pendidikan, staf pengajar, staf karyawan, dan tokoh-tokoh sekitar lembaga. Sumber tertulis diperoleh dari dokumen kegiatan, arsip, brosur, dan sumber lainnya yang mendukung penelitian. Selain itu juga adanya data tambahan yang diperoleh sebagai keabsahan data dengan sumber yang berbeda. Sumber data tambahan diperoleh dari beberapa orang yang berada di sekitar subjek penelitian.

Adapun yang menjadi subjek penelitian ini adalah kepala lembaga, staf pengajar, staf karyawan, dan peserta pelatihan yaitu wanita tuna susila yang berada di BPPS Rangkasbitung Lebak, Banten. Pengumpulan data menggunakan teknik wawancara, observasi dan dokumentasi. Sugiyono (2006), teknik pengumpulan data merupakan langkah yang paling utama dalam penelitian, karena tujuan utama dari penelitian adalah mendapatkan data. Tanpa mengetahui teknik pengumpulan data maka peneliti tidak akan mendapatkan data yang memenuhi standar data yang ditetapkan. Wawancara yang digunakan peneliti bersifat independen yang dilakukan secara open-ended, sistematis dan fleksibel. Wawancara ini diajukan kepada kepala lembaga BPPS, staf pengajar, staf karyawan, dan peserta pelatihan yang berada di lingkungan kantor BPPS Rangkasbitung. Teknik observasi dalam penelitian ini dilakukan untuk mengamati dan membuat catatan secara deskriptif dari mulai survei awal tempat penelitian, permintaan ijin kepada pihak lembaga BPPS untuk dijadikan tempat penelitian, latar belakang BPPS, pengamatan pelaksanaan pembinan dan pelatihan-pelatihan yang dilaksanakan, ketersediaan sarana prasarana, data-data peserta pelatihan WTS, hingga observasi pada tempat masing-masing mantan peserta didik yang telah mengikuti pelatihan tata rias/salon di BPPS Rangkasbitung. Teknik observasi yang dilakukan dalam penelitian ini adalah pengamatan non-partisipatif, yakni penulis tidak ikut melibatkan diri dalam objek penelitian, akan tetapi hanya mengamati langsung di lokasi penelitian. Dokumentasi dilakukan untuk memperoleh data sekunder guna melengkapi data primer yang belum diperoleh melalui teknik observasi dan wawancara. Peneliti juga 
menggunakan teknik dokomentasi berupa daftar nama para peserta didik yang telah mengikuti pelatihan tata rias/salon, struktur organisasi BPPS, laporan hasil wawancara, foto-foto kegiatan penelitian yang berhubungan dengan dampak program pelatihan tata rias/salon terhadap kehidupan sosial-ekonomi.

Instrumen pengumpulan data sebelumnya telah disusun dalam bentuk kisi-kisi yang terbagi atas tiga hal berdasarkan pada fokus penelitian. Kisi-kisi yang pertama adalah pelaksanaan pelatihan, untuk mengetahui pelaksanaan pelatihan yaitu menggunakan indikator; pembukaan, jadwal pelatihan, alokasi waktu, tempat pelatihan, media, metode, sarana dan prasarana, proses, sumber, dan hasil. Kisi-kisi yang kedua yaitu menggunakan apakah faktor penghambat dalam pelatihan ini dan disini menggunkan indikatornya yaitu faktor eksternal dan internal. Kisi-kisi yang ketiga yaitu dampak hasil pelatihan menggunakan indikator yaitu kognitif skill, afektif skill, dan psikomotorik skill.

Langkah-langkah pengumpulan data dalam penelitian ini dilakukan dengan tiga tahap, yaitu tahap orientasi, eksplorasi dan member check.

Pada tahap orientasi, dilakukan kegiatan pra survey pada lokasi penelitian guna mendapatkan gambaran yang lengkap dan jelas mengenai permasalahn yang di teliti. Kegiatan pada tahap eksplorasi yaitu melakukan wawancara dengan kepala lembaga BPPS, staf pengajar, staf karyawan, dan peserta pelatihan yang berada di lingkungan kantor BPPS Rangkasbitung. Melakukan observasi terhadap para peserta didik pelatihan tata rias/salon. Mengumpulkan dan menggunakan dokumen yang berkaitan dengan masalah penelitian. Pada tahap member check kegiatan yang dilakukan peneliti adalah mengadakan pengecekan data pada subjek penelitian atau informan atau dokumen untuk membuktikan validitas data yang diperoleh serta melakukan penghalusan data yang diberikan oleh subjek maupun informan, dan diadakan perbaikan, baik dari segi bahasa maupun sistematikanya. Secara rinci tahap member check yang dilakukan antara lain: mengecek ulang data yang dikumpulkan, dan melakukan wawancara ulang bila informasi yang didapatkan dipandang belum lengkap atau diragukan kebenarannya. Adapun keabsahan data menggunakan triangulasi sumber, metode dan teori. Analisis data menggunakan tiga tahapan reduksi data, penyajian data, dan simpulan/verifikasi.

\section{HASIL DAN PEMBAHASAN}

\section{Proses Pelaksanaan Pelatihan}

Berdasarkan hasil wawancara dan observasi yang dilakukan peneliti didapatkan data mengenai bagaimana proses pelaksanaan kegiatan pelatihan tata rias pengantin yang dilakukan di Balai Pemulihan dan Pengembangan Sosial.

\section{Pra Pelatihan Keterampilan}

Dalam pelaksanaan kegiatan pelatihan dibutuhkan persiapan yang sangat matang agar pelaksanaan pelatihan berjalan dengan baik dan lancar. Oleh karena itu para jajaran Balai Pemulihan dan Pengembagan Sosial (BPPS) dan para panitia pelaksanaan pelatihan mengadakan rapat untuk mempersiapkan kedatangan para peserta dan persiapan kegiatan pelatihan tersebut, tidak hanya itu instruktur juga ikut mempersiapkan materi apa yang akan diberikan kepada para peserta didik pelatihan sesuai dengan kebutuhan dan waktu peserta pelatihan peserta didik. Oleh karena itu instruktur perlu mempunyai materi khusus, akan tetapi para panitia melakukan persiapan yang kurang lama dan matang untuk melakukan pelatihan tersebut dan dengan persiapan tersebut pelaksanaan pelatihan bisa berjalan dengan kurang baik dan tidak sesuai dengan yang diharapkan.

\section{Peserta Pelatihan}

Diketahui bahwa dalam pelaksanaan kegiatan pelatihan terdapat 40 orang yang menjadi peserta didik untuk wanita tuna susila dalam keterampilan tata rias dan peserta didik ini hanya lulusan dari tingkat SD, SMP, maupun SMA. Pelaksanaan pelatihan yang dilakukan di Balai Pemulihan dan Pengembangan Sosial terdapat tiga jenis keterampilan yang dilaksanakan untuk wanita tuna susila yaitu tata rias, tata boga, dan menjahit. Dari jumlah peserta keterampilan 
terdapat 40 orang peserta pelatihan untuk ketrampilan tata rias ini yang berasal dari berbagai daerah wilayah Provinsi Banten yaitu Kabupaten Lebak, Kabupaten Pandeglang, Kabupaten Serang, Kabupaten Tangerang, Kota Serang, Kota Cilegon, Kota Tangerang, dan Tangerang Selatan.

\section{Pelaksanaan Pelatihan}

Pelatihan ini sudah ada sejak dulu sewaktu masih menjadi Provinsi Jawa Barat dan sampai sekarang program pelatihan ini masih berjalan walaupun Balai Pemulihan dan Pengembangan Sosial telah menjadi UPT Dinsos Provinsi Banten. Adanya program pelatihan untuk wanita tuna susila sangat membantu, karena dengan adanya pelatihan tersebut para wanita tuna susila bisa memiliki keterampilan dengan keterampilan tersebut para wanita tuna susila bisa membuka usaha sendiri.

Pelaksanaan pelatihan sangatlah dibutuhkan oleh para wanita tuna susila karena mereka membutuhkan keterampilan untuk bisa ikut bersaing dengan yang lain dalam dunia usaha. Pelaksanaan pelatihan ini menggunakan konsep pendidikan berbasis luas. Pendidikan berbasis luas merupakan suatu pendekatan yang mempunyai karakteristik bahwa proses pendidikan bersumber pada nilai-nilai hidup yang berkembang secara luas di masyarakat. Dengan kata lain pendidikan yang dilakukan harus berorientasi lebih luas, kuat dan mendasar agar warga belajar memiliki kemampuan menyesuaikan diri terhadap kemungkinan yang terjadi pada dirinya dalam bidang usaha/pekerjaan. Pelaksanaan pelatihan ini juga menggunakan strategi yang sangat baik untuk peserta pelatihan yaitu strategi perenungan, pelatihan dan penelaahan.

Perenungan sangatlah diperlukan peserta pelatihan pada saat materi bimbingan mental, karena pada dasarnya perenungan dilakukan agar para peserta merenungi tentang nilai-nilai kehidupan. Selain itu melalui perenungan para peserta diharapkan dapat membuat hubungan positif antara berdoa dan kehidupan sehari-hari. Pelatihan dan penelaahan kegiatan ini menjadi komponen paling penting dalam pelaksanaan pemberdayaan, karena dengan pelatihan para peserta didik diharapkan bisa mendapatkan keterampilan dan dapat mengelola hidup dalam merencanakan masa depan.

Dalam pelatihan ini kurikulum yang digunakan adalah kurikulum berbasis kompetensi, karena setiap manusia memiliki kompetensi-kompetensi tertentu sesuai dengan perkembangan usia, status sosial, dan pekerjaannya. Berdasarkan kompetensikompetensi yang ada inilah dirancang sebuah materi/pelajaran yang perlu dimiliki dan dikuasai oleh para peserta didik. Dengan kurikulum yang baik diharapkan agar terbentuknya kemampuan yang cerdas dan mampu bersaing dengan orang lain sehingga dapat meningkatkan kesejahteraan para peserta didik pelatihan yaitu wanita tuna susila.

Model yang dilakukan dalam pelatihan ini yaitu menggunakan model pembelajaran mandiri usaha dimana individu/peserta pelatihan mengambil inisiatif dengan atau tanpa bantuan orang lain. Para instruktur hanya menjadi sebagai fasilitator bagi para peserta didiknya, dengan menggunkan metode ini diharapkan para peserta pelatihan dapat mandiri dan mempunyai inisiatif yang tinggi dalam mengikuti kegiatan pelaksanaan pelatihan tata rias pengantin. Misalnya para peserta pelatihan mampu berinisiatif dan merasa bebas dalam belajar di saat mengikuti pelatihan. Inisiatif merupkan dorongan yang muncul dalam diri peserta pelatihan tanpa adanya pengaruh dari orang lain, semakin orang merasa bebas dalam belajar. Biasanya inisiatif orang tersebut akan tinggi, karena orang yang merasa memiliki kebebasan dalam belajarnya akan lebih bereksperimen terhadap pelatihan tersebut. Agar peserta pelatihan bisa salin berkomunikasi dengan yang lain pada pelaksanaan pun dibagi kelompok-kelompok kecil agar bisa membantu siswa berinteraksi yang satu dengan yang lainnya.

Pelatihan keterampilan di bidang tata rias pengantin merupakan sebuah pembelajaran yang dapat meningkatkan kemampuan dan potensi peserta didik dalam masalah tata rias pengantin untuk mengatasi masalah 
perekonomian. Pada dasarnya, kebanyakan pembelajaran yang dilakukan sekarang ini cenderung lebih menekankan pada aspek "pengetahuan" dan target "meteri" yang cenderung verbalitas dan kurang memiliki daya serap. Seharusnya untuk bisa bersaing di dunia kerja harusnya pembelajarannya lebih ditekankan pada aspek "kompetensi" dan terget "keterampilan". Ini berarti kompetensi tersebut lebih dibutuhkan masyarakat untuk bisa bersaing dengan orang lain di dunia kerja. Dengan adanya kompetensi yang mendalam sebagai bagian dari kepribadian seseorang sehingga dapat digunakan untuk memprediksi tingkah laku seseorang ketika dihadapkan dengan suatu permasalahan dan situasi kompetensi juga dapat menyebabkan atau memprediksi perubahan tingkah laku, dan kompetensi dapat menentukan dan memprediksi apakah seseorang dapat bekerja dengan baik atau dalam ukuran tertentu yang menjadi standar. Oleh karena itu untuk memenuhi kebutuhan masyarakat dalam memberikan keterampilan sekarang ini banyak lembagalembaga tertentu mengadakan pemberian pemahaman akan sebuah keterampilan untuk masyarakat. Salah satunya yaitu di Balai Pemulihan dan Pengembangan Sosial (BPPS) Provinsi Banten.

Dalam pelaksanaan pelatihan ini terdapat beberapa tahapan-tahapan agar pelaksanaan berjalan sesuai dengan yang diharapkan, yaitu proses penerimaaan, proses pelaksanaan, dan tindak lanjut pelatihan. Sebagaimana yang dikemukaaan oleh Sudjana (2000) mengenai langkah-langkah pengelolaan pelatihan diantaranya rekrutmen peserta, identifikasi kebutuhan belajar, sumber belajar, dan kemungkinan hambatan, menentukan dan merumuskan tujuan pelatihan, menentukan alat evaluasi awal dan akhir, menyusun kegiatan pelatihan, pelatihan untuk pelatih, menentukan evaluasi bagi peserta pelatihan, mengimplementasikan pelatihan, evaluasi akhir, dan evaluasi program. Dengan adanya faktorfaktor yang mendukung di dalam pelatihan diantaranya perencanaan yang disusun oleh pengelola/pelaksanaan sudah matang, pemateri/instruktur yang profesional, pengemasan materi, media dan metode yang digunakan disesuaikan dengan kebutuhan para wanita tuna susila dan didukung oleh sarana dan prasarana yang sangat memadai.

Pelaksanaan pelatihan tata rias pengantin ini menggunakan strategi pendekatan pendidikan berbasis luas yaitu suatu pendekatan yang memiliki karakteristik bahwa proses pendidikan bersumber pada nilai-nilai hidup yang berkembang dimasyarakat. Wardiman (1998) menyebutkan pendidikan berbasis luas merupakan sistem baru yang berwawasana sumber daya manusia, berwawasan keunggulan, dan menganut prinsip tidak mungkin membentuk sumber daya manusia yang berkualitas dan memiliki keunggulan kalau tidak diawali dengan pembentukan dasar (pondasi) yang kuat. Untuk mendapatkan hal demikian, panitia menambahkan kegiatan bimbingan mental dan fisik, dengan strategi renungan mengenai materi agama, dan kegiatan seharihari yang telah dilakukan. Dengan demikian diharapkan para peserta mempunyai pondasi yang kuat dalam menjalani kehidupannya nanti. Pada pelaksanannya juga dibentuk kelompokkelompok kecil agar para peserta pelatihan dalam mengikuti pelaksanannya mudah mengenal, memahami, berinteraksi dan bekerjasama dalam mengikuti pelatihan, dalam melaksanakan tugas-tugas yang diberikan oleh instruktur dapat diselesaikan dengan baik karena adanya kerja sama dalam kelompok tersebut sehingga secara tidak langsung kemampuan peserta pelatihan keterampilan tata rias pengantin ini dapat meningkat.

\section{Faktor Penghambat}

\section{Faktor Internal}

\section{Faktor Internal dari Peserta Didik}

Berdasarkan hasil wawancara dan observasi yang dilakukan peneliti mengenai pelatihan tata rias pengantin di Balai Pemulihan dan Pengembangan Sosial yang menjadi faktor penghambat dalam pelatihan keterampilan tata rias adalah pengetahuan awal peserta didik pelatihan mengenai bidang dunia tata rias baru hanya sebatas mengenal dan tidak mengetahui 
kegunaan-kegunaan bagian rias pengantin. Para peserta pelatihan yaitu wanita tuna susila hanya mengetahui tentang tata rias dari majalah, dan cerita dari teman-temannya saja, mereka belum pernah melakukan praktik langsung/mengetahuinya dari yang ahli di bidang rias salon pengantin tersebut. Kurangnya minat baca pada peserta didik ini mengenai modul tentang tata rias pengantin yang diberikan pada saat pelatihan dapat mempengaruhi terhadap pelaksanaan kegiatan, dan kemampuan peserta dalam beradaptasi sangat rendah sehingga menjadi faktor penghambat dalam pelaksanaan pelatihan tata rias pegantin yang dilaksanakan di Balai Pemulihan dan Pengembangan Sosial.

Kesadaran peserta pelatihan untuk mengikuti kegiatan pelatihan masih sangat rendah, karena terdapat peserta pelatihan yang tidak serius dalam mengikuti pelaksanaan pelatihann tersebut. Manfaat mengikuti pelatihan ini sangatlah banyak diantaranya menambah pengetahuan dan kemampuan tentang tata rias pengantin. Akan tetapi pada kenyataannya masih ada wanita tuna susila yang tidak memanfaatkan kegiatan pelatihan ini dengan baik sehingga kemampuan yang diperoleh oleh peserta didik tidak maksimal.

Faktor Internal dari Lembaga Balai Pemulihan dan Pengembagan Sosial

Faktor internal yang menghambat pelaksanaan pelatihan ini dalam mengidentifikasi masalah dan kebutuhan, dalam mendesain pelatihan/kurikulum pelatihan, dalam menyusun acara pelatihan, dalam menyusun acara opening dan closing ceremony, sarana dan prasarana, media yang digunakan dalam proses pembelajaran pelatihan, metode pelatihan yang digunakan dalam pelaksanaan pembelajaran, pengemasan materi pelatihan agar terlihat menarik dan evaluasi terhadap hasil yang diperoleh setelah mengikuti pelatihan.

Identifikasi masalah dilakukan oleh panitia pelaksanaan kegiatan dan dibantu oleh tim assesment. Faktor yang menghambat dalam mengidentifikasi masalah adalah kurangnya fasilitas pendukung dalam melakukan identifikasi, sehingga panitia yang dibantu oleh tim assesment sedikit mengalami kesulitan. Desain pelatihan ini dirancang agar dalam pelaksanaan pelatihan dan hasil dari pelatihan sesuai dengan apa yang diharapkan, yang menjadi penghambat dalam mendesain pelatihan adalah waktu yang sangat relatif singkat.

Penyusunan acara pelatihan disusun oleh panitia pelatihan yang dibantu oleh tim assesment agar dalam pelaksanaan kegiatan pelatihan teratur dan mengurangi kendala-kendala yang mungkin terjadi dalam pelaksanaan kegiatan pelatihan. Dalam menyusun acara, kendala yang dihadapi adalah menentukan waktu acara, kesibukan Balai Pemulihan dan Pengembangan Sosial sehinga dalam acara pembukaan mengalami hambatan. Narasumber/instruktur yang hadir terlambat yang dapat mempengaruhi susunan acara yang telah ada. Sarana dan prasarana yang kurang lengkap dalam pelaksanaan pelatihan, dalam proses kegiatan narasumber/instruktur, panitia dan peserta pelatihan membutuhkan saran dan prasarana yang lengkap untuk digunakan dengan maksimal, sehingga dengan kurangnya sarana dan prasarana dapat mempengaruhi hasil dari kegiatan pelatihan.

Materi pelatihan disusun oleh panitia, tim assesment dan narasumber, materi yang disampaikan harus dikemas agar materi tersebut terlihat menarik dan tidak membosankan untuk para peserta didik pelatihan tata rias pengantin. Faktor penghambat dalam materi ini yaitu terlalu singkatnya materi pelatihan karena waktu yang kurang lama, sehingga peserta pelatihan belum memahami dan menerima informasi pelatihan dengan maksimal ditambah dengan modul yang menjadi gambaran untuk peserta pelatihan sangat terbatas. Dalam menggunakan metode masih menggunakan metode yang biasa dan monoton, sehingga peserta pelatihan merasa bosan dengan apa yang disampaikan. Faktor penghambat dalam evaluasi yaitu ketidakseriusan para peserta didik dan kurangnya sarana dan prasarana untuk melakukan evaluasi, dan keterbatasan waktu sehingga tidak bisa mengetahui semua kemampuan peserta didiknya. 
Faktor internal dari peserta pelatihan yaitu kurangnya pengetahuan dasar para peserta sangatlah kurang. Kurangnya minat baca mengenai modul yang diberikan pada saat pelatihan mempengaruhi terhadap pelaksanaan kegiatan. Kemampuan peserta dalam beradaptasi dengan lingkungan dan peserta lain sangat rendah. Kurangnya kesadaran peserta pelatihan untuk mengikuti kegiatan pelatihan, karena masih terdapat peserta pelatihan yang tidak serius dalam mengikuti pelaksanaan pelatihan tersebut. Manfaat mengikuti pelatihan sangatlah banyak diantaranya menambah pengetahuan dan kemampuan tentang tata ria pengantin itu sendiri. Akan tetapi pada kenyataannya masih ada saja wanita tuna susila yang tidak memanfaatkan kegiatan pelatihan ini dengan baik sehingga kemampuan yang diperoleh oleh peserta didik tidak maksimal. Sedangkan faktor internal dari lembaga pelaksanaannya di antaranya kurangnya sarana dan prasarana yang ada di Balai Pemulihan dan Pengembangan Sosial sehingga sulit untuk melakukan evaluasi kepada peserta dengan serius.

Melihat pernyataan mengenai pengertian tentang pelatihan di atas bahwa proses pendidikan jangka pendek yang menggunakan prosedur yang sistematis dan terorganisir, sehingga banyak peserta yang mengeluh terhadap waktu. Para wanita tuna susila menyambut dengan baik sekali program pelatihan yang diadakan, akan tetapi mereka mengeluhkan terhadap waktu yang relatif sangat singkat. Dengan waktu pelatihan yang sangat singkat, peserta pelatihan mengharapkan dengan adanya kegiatan pelatihan yang berkelanjutan, sehingga dengan demikian para peserta pelatihan benar-benar dapat meningkatkan kompetensi mereka di bidang tata rias pengantin. Kendala lainnya adalah kurangnya modul belajar merupakan salah satu faktor pendukung dalam proses pelatihan, sehingga dengan tidak adanya modul dalam proses pelaksanaan peserta pelatihan mereka kesulitan dalam mengikuti materi yang disampaikan oleh instruktur.

\section{Faktor Eksternal}

\section{Faktor Eksternal Lembaga Balai Pemulihan dan Pengembagan Sosial}

Terdapat faktor eksternal dalam pelaksanaan pelatihan yang dilakukan oleh pihak Balai Pemulihan dan Pengembahan Sosial yaitu tidak adanya kerja sama dengan pihak manajemen (lingkungan kerja). Agar para peserta pelatihan dapat mempraktikkan langsung apa yang telah mereka dapatkan selama dari pelatihan ini, dukungan dari pihak manajemen sangatlah penting karena dengan adanya demikian mungkin adanya transfer/penempatan peserta pelatihan untuk bekerja di tempat stake holder.

\section{Dampak Hasil Program Pelatihan}

Berdasarkan hasil wawancara dan observasi yang dilakukan oleh peneliti mengenai hasil kegiatan pelatihan, ditemui bahwa para peserta pelatihan (wanita tuna susila) yang mengikuti kegiatan ini hampir $85 \%$ peserta pelatihan lulus dengan baik dan mendapat keterampilan yang mendalam di bidangnya, mendapatkan ilmu pengetahuan yang layak bagi dirinya, dan terbentuk kembali sikap serta prilaku wanita tuna susila sesuai dengan nilai dan norma yang berlaku di lingkungannya masing-masing. Setelah pelatihan ini selesai, para peserta wanita tuna susila harus dibina dan dibimbing untuk mendapatkan motivasi yang lebih dalam belajarnya. Dengan mengikuti pelatihan tata rias pengantin ini, para peserta bisa mandiri dan berwirausaha dengan keterampilannya di bidang tata rias. Dengan demikian, para peserta dapat mencukupi kebutuhannya sendiri dan bahkan dapat membantu perekonomian keluarganya. Tidak hanya pemahaman tentang tata rias pengntin para peserta juga diberikan materi tambahan untuk kebutuhan rohaninya, yaitu dengan diadakannya bimbingan mental dan pengajian para peserta dapat lebih rajin beribadah dan dekat lagi dengan Allah SWT.

Hasil pelatihan dapat tercapai karena adanya manajemen, metode pelatihan dan prinsip-prinsip pembelajaran yang digunakan sesuai dengan jenis pelatihan yang diberikan. 
Meskipun tidak ada metode yang paling sempurna, namun dapat dicari beberapa metode alternatif yang sesuai dengan pelatihan tersebut. Menurut Moekijat (1993) menyampaikan tujuan umum pelatihan sebagai berikut adalah untuk mengembangkan keahlian, sehingga pekerjaan dapat diselesaikan dengan lebih cepat dan lebih efektif. Untuk mengembangkan pengetahuan, pekerjaan dapat diselesaikan secara rasional, dan untuk mengembangkan sikap, sehingga menimbulkan kemauan kerja sama dengan teman-teman, pegawai, dan dengan manajemen (pimpinan). Melihat pernyataan mengenai tujuan pelatihan bahwa dengan mengikuti pelatihan peserta dapat mengembangkan keahlian, sehingga pekerjaan dapat diselesaikan dengan lebih cepat dan lebih efektif dan untuk mengembangkan keahlian, untuk mengembangkan pengetahuan sehingga pekerjaan dapat diselesaikan dengan rasional. Jadi dengan adanya pelatihan keterampilan tata rias pengantin sangat membantu peserta dalam meningkatkan keahlian dan kompetensi peserta pelatihan. Akan tetapi, bagi para peserta yang lulus pelatihan ini tidak semuanya menggunakan keahlian yang didapatkannya dalam pelatihan untuk bekerja, masih banyak peserta pelatihan yang lulus kembali ke pekerjaan sebelumnya yang mereka geluti.

Materi komputer juga diberikan untuk menunjang para peserta bisa mahir dan memahami tentang teknologi informasi supaya tidak ketinggalan jaman. Akan tetapi, dalam penerapannya hanya sedikit peserta yang berwirausaha dan mandiri dalam mencukupi kebutuhan mereka. Ketika diadakan bimbingan lanjut kepada peserta pelatihan yang telah lulus mereka kebanyakan ada yang membuka wirausaha sebagai penata rias pengantin dan ada juga membuka usaha salon wanita, dan tidak sedikit pula yang kembali ke profesi/pekerjaan yang awal sebagai wanita penghibur dan tidak menggunakan keahlian yang telah mereka dapatkan dari pelatihan tersebut dan banyak dari mereka yang menjual barang-barang bantuan yang diberikan kepada mereka. Bagi peserta yang bertahan dan bisa mandiri juga akan mendapat bantuan stimulan dari pihak Balai Pemulihan dan Pengembangan Sosial.

\section{SIMPULAN}

Kegiatan pemberdayaan wanita tuna susila dengan pelatihan tata rias pengantin dalam meningkatkan kemandirian usaha di Balai Pemulihan dan Pengembangan Sosial Rangkasbitung mencakup tiga aspek, proses pelaksanaan, faktor penghambat pelaksanaan, dan dampak hasil pelaksanaan pelatihan. Pelaksanaan pelatihan tata rias pengantin dilaksanakan di Balai Pemulihan dan Pengembangan Sosial berlangsung selama 33 hari sesuai dengan apa yang diharapkan. Jumlah peserta yang mengikuti pelatihan sebanyak 40 peserta pelatihan dan waktu yang diberikan oleh lembaga satu minggu lima kali pertemuan serta jadwal yang diberikan pada pukul 07.30 WIB sampai dengan 14.30 WIB.

Faktor penghambat internal pada peserta pelatihan adalah kurangnya alat-alat tata rias untuk melaksanakan pelatihan yang disediakan oleh Balai Pemulihan dan Pengembangan Sosial, kurangnya tenaga pengajar, serta waktu yang diberikan terlalu singkat. Faktor eksternal penghambat pelaksanaan pelatihan adalah kurangnya sarana dan prasarana yang mendukung untuk melaksanakan pelatihan tata rias. Adapun dampak hasil pelaksanaan pelatihan adanya peserta pelatihan lulus dengan baik, akan tetapi para peserta tidak semuanya mandiri dan berwirausaha dengan keterampilannya dari peserta didik ini yang mengikuti pelatihan yang berjumlah 40 orang sebagian diantaranya 20 orang membuka usaha sendiri, 10 orang bekerja disalon, 5 orang lagi tidak jelas, dan 5 orang lagi kembali ke profesi semula yaitu sebagai wanita penghibur.

Diharapkan bagi pengelola dalam proses pelaksanaan pelatihan tata rias pengantin kurangnya teori-teori mengenai hal tata rias, lebih ditingkatkan guna menunjang pelatihan tata rias yang lebih memenuhi standar pelaksanaan pelatihan. Bagi lembaga Balai Pemulihan dan Pengembangan Sosial memberikan sarana dan prasarana yang memenuhi standar pelaksanaan tata rias, dan 
bisa menambah tenaga pendidik guna menunjak pelaksanaan pelatihan yang baik. Bagi peserta didik wanita tuna susila tidak kembali lagi kepada dunianya sebelumnya, lebih berusaha untuk menerapkan hasil kegiatan yang diperoleh dalam pelatihan.

\section{DAFTAR PUSTAKA}

Budiman. (2006). Konsep-konsep dalam kemandirian usaha. Jakarta: Erlangga.

Harpi Melati Temanggung. (1998). Pelatihan Tata Rias. Jakarta: Rineka Cipta.

Hendriyani. (2005). Kemandirian usaha. Bandung: Alfabeta.

Moekijat, D. (1993). Evaluasi pelatihan dalam rangka peningkatan produktivitas. Bandung: Mandar Maju.

Ningsih. (2005). Kemandirian Usaha Perilaku. Jakarta: Raja Grafindo Persada.

Saleh, R., \& Jafar, A. (1991). Teknik dasar pembuatan busana. Jakarta: Departeman Pendidikan Dan Kebudayaan.

Sudjana, D. (2000). Manajemen program pendidikan untuk pendidikan luar sekolah dan pengembangan sumber daya manusia. Jakarta: Falah Production.

Sugiyono. (2006). Metode penelitian pedidikan. Bandung: Alfabeta.

Wardiman, D. (1998). Pengembangan sumberdaya manusia melalui sekolah menengah kejuruan (SMK). Jakarta: Depdikbud. 